\title{
Pemikiran Filsuf Barat Dan Islam Terhadap Konsep Dinamika Gerak
}

\author{
Hendri Saputra \\ Program Studi Pendidikan Fisika Universitas Samudra \\ e-mail: hendri saputra@yahoo.com
}

\begin{abstract}
Gerak merupakan fenomena esensial pada segala sesuatu yang mewaktu, dalam hal ini apa pun yang termasuk dalam maujud material adalah identik dengan gerak itu sendiri. Namun, di dalam istilah filsafat, gerak mempunyai pengertian yang lebih luas, akan tetapi, harus diperhatikan bahwa di dalam istilah filsafat, tidak semua perubahan dapat disebut gerak. Tujuan dari penulisan artikel ini adalah untuk membahas pemikiran tokoh falsafat barat dan islam terhadap fenomena dinamika gerak dan implikasinya dalam pembelajaran fisika. Selanjutnya, akan dibahas bagaimana menyinergikan antara pemikiran sains dan islam. Metodologi penulisan artikel ini berdasarkan hasil kajian literatur sebelumnya yang relevan. Pemikiran filsuf barat dan islam pada pola berfikir mereka yang menjelaskan tentang fenomena gerak yang terjadi di tatanan alam semesta ini. Dapat dikatakan bahwa semua realitas pada dasarnya adalah dinamis. Karena selalu ada perubahan baik itu dipengaruhi faktor eksternal maupun bergerak dengan sendirinya. Terkait hubungan sains dan Islam berkaitan dengan alam dapat dipandang dalam dua hal, Pertama, Sains dalam kacamata alam sebagai kesatuan tunggal dengan segala bagiannya saling terkait satu sama lain. Kedua. Sains dimaksudkan untuk mendorong baik saintis maupun filsuf untuk merenungkan alam sebagai ciptaan Tuhan.
\end{abstract}

Keywords: Filsuf Barat, Konsep Dinamika

\section{Pendahuluan}

Perkembangan sains abad 21 ini tidak terlepas dari perkembangan teknologi, politik, ekonomi, sosial, dan filsafat yang berkembang di dalam masyarakat. Catatan sejarah menujukkan perubahan yang signifikan terjadi di abad 21 ini. Perubahan-perubahan tersebut berkembang dari filsafat yang dianut oleh masyarakat hampir dari seluruh dunia di masa sebelumnya (Tafsir, 2009). Ada dua kekuatan yang mempengaruhi peradaban yaitu agama dan filsafat (Nasution, 2016). Kedua kekuatan tersebut sampai hari ini bersaing untuk mempengaruhi manusia dengan janji-janji keselamatan dan kemajuan. Akibat dari pemikiran filsafat telah menghasilkan beragam ilmu pengetahuan seperti ilmu sosial, ilmu alam (Sains).

Sains pada hakikatnya adalah sebuah kumpulan pengetahuan (a body of knowledge), cara berpikir (a way of thinking), dan cara untuk melakukan investigasi atau penyelidikan (a way of investigating) (Collette \& Chiappetta, 1994). Sains sebagai kumpulan pengetahuan ditandai dengan adanya fakta, konsep, hukum, dan teori, sebagai cara berpikir ditandai dengan adanya proses berpikir untuk mengambarkan rasa penasaran terhadap fenomena alam, dan sebagai cara penyelidikan ditandai dengan penggunaan metode ilmiah untuk memahami gejala-gejala alam atau yang terkait dengan sains. Berbicara hakikat sains sama halnya dengan berbicara hakikat fisika, sebab fisika merupakan salah satu rumpun ilmu dalam sains. Oleh karenanya, karakteristik sains sama dengan karakteristik fisika. Supahar (2014) menjelaskan hakikat fisika terdiri dari fisika sebagai produk dan sekumpulan pengetahuan (physics as product aspect or a body knowledge), fisika sebagai sikap atau cara berpikir (physics as an attitude aspect or a way of thinking), dan fisika sebagai proses atau cara melakukan investigasi (physics as a process or away of a investigation).

Berbicara fisika tidak terlepas dengan bicara gerak. Gerak merupakan fenomena esensial pada segala sesuatu yang mewaktu, dalam hal ini apa pun yang termasuk dalam maujud material adalah identik dengan gerak itu sendiri. Sehingga tidak ada apa pun di alam ini yang diam dan vakum. Seluruhnya senantiasa berada dalam perubahan terus-menerus tanpa pernah sedikitpun berhenti. Sedangkan perubahan itu sendiri tidak mungkin terjadi, jika tidak ada sebab 
yang mendasarinya. Setiap gerak dan perubahan selalu merupakan akibat dari satu kehendak untuk mencapai tujuan tertentu.

Gerak mempunyai banyak ragam dan bentuk. Gerak biasanya didefinisikan sebagai pergeseran suatu objek dari satu titik ke titik yang lain. Juga bisa dianggap sebagai suatu gerak jika konstituen suatu objek, dan bukan objek itu sendiri, berubah kedudukannya seperti perputaran pada suatu kincir angin. Namun, di dalam istilah filsafat, gerak mempunyai pengertian yang lebih luas: pada sebuah apel, perubahan warna dari hijau menjadi kuning dan berubah lagi menjadi merah juga disebut sebagai gerak yaitu gerak kualitatif, demikian juga pertumbuhan sebuah pohon dari kecil menjadi pohon yang besar disebut gerak kuantitatif. Akan tetapi, harus diperhatikan bahwa di dalam istilah filsafat, tidak semua perubahan dapat disebut gerak. Pergeseran atau perubahan keadaan suatu objek dapat disebut sebagai gerak jika dua syarat terpenuhi. Pertama, perubahan itu tidak boleh terjadi secara 'tiba-tiba' tetapi harus gradual selangkah demi selangkah/berangsur-angsur, perubahan juga harus mempunyai ekstensi (perpanjangan), temporal (sementara), walaupun hanya sesaat saja. Kedua, perubahan itu harus mempunyai ekstensi yang dapat dibagi secara yang tak terbatas, bukan kumpulan atom-atom yang tidak dapat dibagi (seperti dalam paham atomisme) (Al-Mandary, 2003).

Banyak tokoh filsafat barat yang telah menyumbangkan pikirannya mulai dari abad yunani kuno, pertengahan, dan abab modern seperti Plato, Aristoteles, Thomas Azquinas, Hegel dan tokoh-tokoh lainnya. Selain tokoh filsafat barat, juga banyak tokoh filsafat islam yang menyumbangkan pikiriran mereka tentang gerak seperti Alkindi, Ibnu Sina, Ibnu Bajjah dan Mulah Shadra. Dikalangan intelektual muslim, sebenarnya terjadi dua pendapat mengenai masalah perbedaan antara teori ilmu (epistemologi) Islam dan modern. Pertama. Kelompok yang menampilkan perbedaan tersebut, kelompok ini berpendapat bahwa ilmu pengetahuan bersifat objektif sehingga perbedaan antara ilmu modern dan Islam adalah semu. Kedua, Kelompok yang membenarkan adanya perbedaan fundamental antara epistemologi modern dan Islam (Kartanegara, 2007).

Pertimbangkan perbedaan fundamental antara sudut pandang yang digunakan oleh ilmuwan Barat dan Islam tersebut, menunjukkan bahwa usaha Islamisasi sains sangat dibutuhkan untuk memberikan perspektif spiritual atau nilai-nilai agama yang mulai pudar dari aspek fundamental bangunan keilmuan modern, yang didominasi oleh Barat. Jargon-jargon tentang ilmu pengetahuan bebas nilai, Positivisme, Materialisme, dan Sekularisme di bidang sains yang dikembangkan oleh Barat, ternyata telah menyebabkan krisis identitas kemanusiaan, dan menyebabkan manusia semakin jauh dari agama dan Tuhan (Katanegara, 2002). Oleh sebab itu, posisi umat Islam sebagai konsumen teknologi diharapkan dapat berubah menjadi produsen teknologi modern secara perlahan-lahan. Sinergi agama dan sains juga akan menjadikan identitas dan memberikan nilai tambah terhadap lembaga-lembaga pendidikan Islam. Dengan demikian,pensinergian antara agama dan sains secara totalitas merupakan hal yang tidak boleh ditunda lagi. Tujuan dari penulisan artikel ini adalah untuk membahas pemikiran tokoh falsafat barat dan islam terhadap fenomena dinamika gerak yang harapannya dapat memberikan pemahaman terhadap perkembangan konsep gerak dalam mekanika klasik.

\section{Metode}

Artikel ini dibuat dengan menggunakan metode penelitian kualitatif dengan pendekatan filsafat sejarah sains barat dan islam. Adapun metode yang digunakan untuk mengumpulkan data adalah metode studi pustaka, yaitu dengan mencari informasi baik dari buku, jurnal dan artikel.

\section{Hasil dan Pembahasan}

Teori Dinamika Gerak menurut filosofi barat.

Pengkajian tentang alam semesta bukan merupakan hal baru dalam kajian filsafat, yaitu dimulai dari abad yunani kuno, pertengahan, dan abad modern. Pada abad yunani kuno sering disebut periode filsafat alam yang ditandai dengan munculnya para ahli pikir alam, dimana arah dan pemikirannya apa yang diamati (Farikhah, 2013). Memeka membuat pertanyaanpertanyaan tentang gejala alam berdasarkan akal dan pikiran tidak berdasarkan pada mitos.

Pemikiran gerak abad yunani kuno diawali oleh pemikiran Demokritus (460-370 SM) yang dilahirkan Dikota Abdera, Yunani Utara. Menurutnya gerak sebagai ciri yang melekat pada 
atom-atom. Gerak sendiri merupakan karakteristik hakiki dari semua atom. Gerakan itu abadi. Segala sesuatu dalam alam semesta dapat dihitung bila dipandang dari segi distribusi atomatom yang bergerak sendiri yang bergerak dalam uang-ruang kosong. Sebagaimana atom-atom tidak dapat direduksi dan tidak dapat dijelaskan oleh sesuatu yang lebih fundamental, demikian juga gerak tidak dapat direduksi dan tidak memerlukan sumber penjelasan lebih lanjut. Intinya perubahan menurut Democritus adalah perubahan dari suatu bentuk ke bentuk yang lain, sedangkan ciri atau watak alamiah tidak mengalami perubahan (Fahham, 2004).

Selanjutnya, Plato (427SM -347 SM) membagi gerak dalam dua jenis yaitu gerak yang diberlakukan diluar benda, dan gerak yang bergerak sendiri tampa ada gaya yang diberikan dari luar. Gerak yang diberikan dari luar pada akhirnya tergantung pada gerak abadi dan yang bergerak sendiri dalam jiwa-jiwa (roh-roh). Pada akhirnya semua gerak dalam alam semesta tergantung pada aktivitas suatu jiwa dunia. Plato mempertahankan bahwa materi itu sendiri tidak aktif. Satu-satunya hal yang dapat menggerakkan hal-hal lain yang tidak bergerak adalah jiwa, yang dapat menggerakkan dirinya sendiri (bergerak sendiri secara abadi). Karena jiwa dapat menggerakkan dirinya sendiri, maka juga dapat menggerakkan hal-hal yang tidak bergerak. Jiwa merupakan sebab primer dari gerakan (perubahan). Dunia real ide-ide tidak bergerak. Ide itu sempurna, tetap dan tidak berubah. Dunia yang kelihatan serta ilusif bergerak terus menerus (mengalir terus menerus, berubah). Plato berpandangan bahwa materi dalam dirinya sendiri cenderung untuk diam. Satu-satunya benda yang dapat menggerakkan benda lain yang tidak bergerak adalah jiwa, yang dapat menggerakkan dirinya sendiri (senantiasa dalam keadaan bergerak). Karena ia dapat menggerakkan dirinya sendiri ia juga dapat menggerakkan benda-benda yang tak dapat bergerak. Jiwa adalah kausa prima dari gerak (perubahan). Dunia bentuk-bentuk yang nyata tidak bergerak. Bentuk-bentuk sempurna, tidak dapat diubah, dan tidak berubah. Dunia khayal yang terindera ini selalu berada dalam gerak (fluks, perubahan).

Pemikiran gerak abad yunani kuno dilanjutkan oleh Aristoteles (384 SM-322 SM) merupakan murid dari Plato. la Berpandangan gerak yang terus-menerus itu tidak mungkin. Aristoteles meyakini bahwa gerak atau perubahan yang terjadi pada sesuatu adalah perubahan bagian luar. Dengan kata lain, gerak selalu disebabkan oleh gaya (berupa tarikan atau dorongan), gerobak bergerak karena ditarik oleh seekor kuda, kapal layar bergerak karena didorong oleh angin. Jadi, gerak selalu disebabkan oleh gaya luar yang bekerja pada benda Jika pada benda yang bergerak sama sekali tidak ada gaya luar yang bekerja maka suatu waktu benda akan kembali ke keadaan alaminya, yaitu diam. Benda tidak mungkin bergerak karena dirinya sendiri.

Memasuki abad pertengahan pembahasan mengenai alam semesta diletakkan dalam dimensi agama (Hambali, 2012). Artinya, pemikiran filsafat abad pertengahan didominasi oleh agama. Pemecahan semua persoalan selalu didasarkan atas dogma agama, sehingga corak pemikiran kefilsafatannya bersifat teosentris. Masa abad pertengahan ini juga dapat dikatakan sebagai suatu masa yang penuh dengan upaya menggiring manusia ke dalam kehidupan/ sistem kepercayaan yang picik dan fanatik (Farikhah, 2013). Tokoh Filsafat Pada abad ini Thomas Aquinas (1225-1274 M). Menurut Thomas: (1) Segala sesuatu di dunia ini selalu berada dalam proses perubahan; (2) Sesuatu yang ada dalam proses perubahan itu tidak dapat menyebabkan perubahan tersebut dalam dirinya, yang melakukannya adalah sesuatu yang lain. (3) Apabila yang melakukan perubahan itu dapat juga diubah oleh sesuatu yang lain lagi, maka setiap orang bisa menyusun 'yang mengubah' dan 'yang diubah' dalam satu rangkaian. Rangkaian 'yang mengubah' dan 'yang diubah' tanpa berkesudahan adalah mustahil; (4) Oleh karena itu harus ada penyebab pertama dari perubahan yang mengawali rangkaian 'yang mengubah' dan 'yang diubah' dimana dia sendiri tidak menerima proses perubahan tersebut, dan itu adalah Tuhan. Dari uraian di atas dapat diambil suatu kesimpulan bahwa gerak menurut Thomas Aquinas gerak adalah perubahan itu terjadi karena adanya suatu penyebab.

Pada abad modern peralihan yang diisi dengan gerakan kerohanian yang bersifat pembaharuan. Zaman peralihan ini merupakan embrio massa modern. Zaman ini ditandai dengan munculnya renaissance yang berarti kelahiran kembali, yang mengacu pada gerakan keagamaan dan kemasyarakatan di Italia (Pertengahan Abad 14). Tujuan utamanya adalah merealisasikan kesempurnaan pandangan hidup Kristiani dengan mengaitkan filsafat Yunani dengan ajaran agama Kristen. Selain itu, juga dimaksudkan untuk mempersatukan kembali gereja yang terpecah-pecah (Achmadi, 2001). Pandangan filsuf barat tentang pikiran gerak dipelopori oleh Descartes dan Hegel sebagai berikut. Menurut Descartes (1596-1650 M) bahwasanya substansi yang terbentang dalam ruang, yaitu bentuk- bentuk material yang merupakan bahan susunan alam materil indrawi yang diatur oleh suatu sistem mekanis, dimana 
seandainya suatu bentuk materil tertentu bergerak, maka gerakannya akan beralih kepada gerakan selanjutnya dan begitu terus sampai tak terhingga yang menjadikan materi dan membuat semuanya bergerak. Sehingga, menurutnya, pengetahuan berjalan atau bergerak dari wilayah rasional kepada wilayah inderawi.

Berbeda dengan pandangan gerak menurut Descartes, Hegel (1770-1831) dalam diktum yang terkenal adalah Alles vernunftige ist wirklich und alles wirkuche istvernunftig, yaitu segala yang rasional adalah real dan segala yang real adalah rasional. Jadi, struktur pikiran sama dengan struktur kenyataan atau ide yang dimengerti dari kenyataan itu adalah sama. Karena proses gerak pemikiran adalah sama dengan proses gerak kenyataan, maka hal itu menunjukkan hilangnya perbedaan rasio dan realitas. Dengan demikian, pengertian-pengertian, kategori-kategori, sebenarnya bukan hukum-hukum pemikiran belaka, namun merupakan kenyataan-kenyataan. Jadi dalam filsafat sejarah Hegel, dasar dari gerak adalah dialektika (tesis, anti-tesis, sintesis), yang merupakan mekanisme esensial bagi gerak alam, dan melalui mekanisme inilah ruh berkembang.

\section{Pemikiran Dinamika Gerak menurut Filsuf Islam.}

Gerak dalam pemikiran islam sumber pokok yang mereka manfaatkan adalah nash-nash agama. Ini dapat dilihat terutama pada aliran Mu'tazilah dan Asy'ariyah (Farikhah, 2013). Ciri khas paling khusus dari Mu'tazilah ialah bahwa mereka meyakini sepenuhnya kemampuan akal. Ciri khas paling khusus dari Mu'tazilah ialah bahwa mereka meyakini sepenuhnya kemampuan akal. Berbeda dengan mu'tazilah, menurut Asyariyah, suatu perbuatan tidak akan terwujud tanpa adanya pencipta (muhdits). Proses terjadinya suatu perbuatan harus ada kehendak dari sang pencipta. Pencipta yang memiliki kehendak itu tidak lain hanyalah Allah, Tuhan yang Maha berkuasa dan maha berkehendak. Tokoh filsuf islam yang menymbangkan idenya terhadap konsep dinamika gerak adalah Alkindi, Ibnu Sina, Ibnu Bajjah, dan Mulah Sadra.

Pekikiran konsep gerak di awali oleh Alkandi (801-873M) nama lengkapnya Abu Yusuf Ya kub ibn Ishaq ibn Sabbah ibn Imran ibn Ismail al-Ash`ats ibn Qais al-Kindi. Menurutnya tiaptiap gerak berarti merupakan bilangan massa benda, dan oleh karena itu maka gerak hanya terdapat pada apa yang mempunyai zaman. Berdasarkan ini, maka gerak itu ada, apabila ada benda, karena tidak mungkin ada benda yang semula diam kemudian bergerak, sebab benda alam ini adakalanya baharu atau qadim. Kalau baharu, maka wujudnya dari tiada adalah kejadian sedang kejadian merupakan salah satu macam gerak. Jadi baharu-nya benda alam adalah gerakan dan oleh karena itu baharu dan gerak selalu begandengan. Jika benda itu qadim dan diam yang mungkin bisa bergerak, kemudian bergerak sesudah itu, maka hal ini berarti bahwa sesuatu yang azali mengalami perubahan. Akan tetapi yang qadim tidak mungkin mengalami perubahan (Hanafi, 1996). Jadi menurut Al-Kindi Gerak adalah perubahan keadaan, perubahan yang menyangkut hanya ruang setiap bagian massa itu saja, adalah gerak ruang, perubahan tempat batas-batas masa itu.

Selanjutnya, Ibnu Sina (980-1038 M) dilahirkan di desa Afsyanah, dekat Bukhara, di kawasan Asia Tengah. Menurutnya gerak ialah pergantian keadaan yang menetap pada benda. Sedikit demi sedikit, dengan menuju kepada arahnya yang tertentu. "Tiap-tiap gerak terdapat pada perkara yang bias bertambah atau berkurang, sedang jawhar (benda-benda kecil/atomatom) tidak demikian keadaannya (tidak mengenal gerak). Dengan demikian, maka kejadian jauhar dan kemusnahannya tidak merupakan gerak, melainkan sesuatu yang terjadi dengan sekaligus (Akhyar, 1993). Ibnu Sina menggambarkan gerakan sebagai dua proses subjektif dan objektif. Pada proses subjektif, terjadinya proses bertahap (tadrij) dari satu titik menuju titik berikutnya melintasi ruang sehingga terjadi gerakan. Kondisi ini, menurut dia hanya terjadi secara objektif pada diri pengamat karena penggabungan titik-titik tersebut menjadi satu bagian yang tergabung hanyalah terjadi pada persepsi subjek, sedangkan secara objektif, wujud yang di persepsi bergerak itu bersifat permanen berada di antara permulaan dan akhir.

Tokoh selanjutnya adalah Ibnu Bajjah (1082-1138 M) nama lengkapnya adalah Abu Bakar Muhammad bin Yahya bin ashshayighat-Tujibi bin Bajjah adalah seorang astronom, filosuf, musisi, dokter, fisikawan, psikolog, botanis, sastrawan, dan ilmuwan muslim Andalusia yang dikenal di Barat dengan nama lainnya Avempace. Dalam bidang fisika, Ibnu Bajjah mengungkapkan hukum gerak. Prinsip-prinsip yang dikemukakannya itu menjadi dasar bagi pengembangan ilmu mekanik modern. Pemikirannya dalam bidang fisika banyak memengaruhi fisikawan Barat abad pertengahan, seperti Galileo. Tak heran, jika hukum kecepatan yang dikemukakannya sangat mirip dengan yang dipaparkan Galileo. Ibnu Bajjah mendefinisikan tentang kecepatan pada saat benda bergerak, yang mana definisi tersebut sama dengan 
definisi dari Galileo. la menyatakan bahwa Kecepatan =Gaya gerak-Resistansi Materi (Ernest,1951). Gaya gerak diukur dengan gravitasi spesifik benda yang bergerak dan resistansi material adalah media penahan yang daya resistannya diukur dengan gravitasi spesifik nya. Ibn Bajjah adalah orang pertama yang menyatakan bahwa selalu ada gaya reaksi untuk setiap gaya yang diberikan, pendahulu gagasan Gottfried Leibniz tentang gaya yang mendasari hukum gerak ketiga Newton atau hukum aksi-reaksi (Shlomo,1964). Selain dari itu, mengemukakan teori berkaitan dengan gerak dalam ruang hampa. Analisisnya mengenai gerak "alami" seperti batu jatuh melalui udara dan air (Putri, 2017). Benda-benda yang bergerak ini membutuhkan daya untuk bergerak tidak hanya pada cara bagaimana gerakan benda tersebut, tetapi juga melalui media melalui mana benda tersebut akan bergerak. Partikel debu tetap melayang di udara karena, meskipun memiliki daya yang cukup untuk turun, daya tersebut tidak cukup untuk melewati udara.

Mulla Shadra (1572-1640 M) nama lengkapnya adalah Muhammad Ibnu Ibrahim Ibnu Yahya Qawami Al-Syirazi la lahir di Syiraz, sebuah kota paling terkenal di Iran. Menurut Mulla Shadra, gerak adalah perubahan suatu objek dari potensialitas menuju aktualitas (Farikhah, 2013). Dalam pembahasannya tentang gerak, Shadra menunjukkan berbagai jenis gerak. la menyatakan, gerak itu ada dua jenis : jenis pertama adalah gerak dalam pengertian qath'. Di sini, gerak merupakan proses tunggal, berkelanjutan, dan tersatukan dari awal hingga akhir. Proses berkelanjutan ini terpatri dalam imajinasi dan ini disebabkan oleh gerak dalam pengertian tawassuțiyyah. Jenis gerak lain adalah proses berubah-ubah yang secara bertahap menjadi eksis di luar. Ini termasuk gerak dalam pengertian tawassuțhiyyah dan agen penggerak dalam pengertian qath". Jika para pemikir terdahulu menyatakan bahwa benda terbagi menjadi yang menetap dan yang berubah, filsafat Mulla Shadra menyatakan kemustahilan adanya sifat yang tetap dan stabil pada benda. Oleh karena itu, Mulla Shadra menyatakan bahwa sebagian tingkat wujud yang merupakan hakikat manunggal dan sejati ada yang bersifat menetap dan ada yang bersifat mengalir dan bahwa tingkatan wujud yang menetap berada di luar wilayah fisik.

\section{Pemikiran gerak Menurut Galilio dan Ishak Newton}

Pemikiran gerak Menurut Galilio dan Ishak Newton merupakan awal perkembangan teori fisika kalasik. Galileo Galilei (1564-1642 M) adalah seorang yang berpengetahuan luas dan sangat teliti; Beliau dipandang sebagai Bapak Fisika Eksperimental. Pemikiran newton tentang gerak didasarkan pada penemuan Galileo dikenal sebagai sifat kelembaman yaitu "jika tidak ada gaya yang diberikan kepada benda yang bergerak, benda itu akan terus bergerak dengan laju konstan pada lintasan yang lurus (Gioncoli, 2001). Sebuah benda melambat hanya jika ada gaya yang diberikan kepadanya. Dengan demikian, Galileo menganggap gesekan sebagai gaya yang sama dengan dorongan atau tarikan biasa. Sebagai contoh, mendorong sebuah buku melintasi meja dengan laju tetap dibutuhkan gaya dari tangan kalian, hanya untuk mengimbangi gaya gesekan. Selain Galilio, filsuf islam seperti Ibnu Bajjah juga memberikan kontribusi dengan teorinya bahwa "kecepatan pada saat benda bergerak adalah sebanding dengan kecepatan akhir dan hambatan dari medium nya. $V=F-R$, di mana $F$ adalah gaya saat benda bergerak dan $\mathrm{R}$ adalah resistansi atau hambatan yang dalam hal ini adalah udara. Artinya pada saat hambatan udara diabaikan maka benda akan jatuh pada percepatan yang sama, karena udara merupakan suatu hambatan yang dapat memperlambat pergerakan benda.

Berdasarkan penemuan ini, Isaac Newton (1642-1727 M), membangun teori geraknya yang terkenal. Analisis Newton tentang gerak dirangkum dalam "tiga hukum gerak"-nya yang terkenal. Dalam karya besarnya, Principia (diterbitkan tahun 1687), Newton menyatakan terima kasihnya kepada Galileo. Pada kenyataannya, hukum pertama Newton tentang gerak sangat dekat dengan kesimpulan Galileo. Hukum I Newton menyatakan bahwa: Setiap benda tetap berada dalam keadaan diam atau bergerak dengan laju tetap sepanjang garis lurus, kecuali jika diberi gaya total yang tidak nol (Resnik, 2001).

$\sum \mathrm{F}=0$

Kecenderungan sebuah benda untuk mempertahankan keadaan diam atau gerak tetapnya pada garis lurus disebut inersia (kelembaman). Sehingga, Hukum I Newton sering disebut Hukum Inersia. Hukum I Newton tidak selalu berlaku pada setiap kerangka acuan. Sebagai contoh, jika kerangka acuan kalian tetap di dalam mobil yang dipercepat, sebuah benda seperti cangkir yang diletakkan di atas dashboard mungkin bergerak ke arah kalian (cangkir tersebut tetap diam selama kecepatan mobil konstan). Cangkir dipercepat ke arah kalian tetapi baik kalian maupun orang atau benda lain memberikan gaya kepada cangkir tersebut dengan arah berlawanan. Pada kerangka acuan yang dipercepat seperti ini, Hukum I 
Newton tidak berlaku. Kerangka acuan di mana Hukum I Newton berlaku disebut kerangka acuan inersia.

Hukum II Newton Perubahan gerak suatu benda berbanding langsung dengan kekuatan yang bekerja padanya dan perubahan seperti itu terjadi dalam arah garis lurus dari mana kekuatan itu datang. Artinya, dalam hukum kedua menjelaskan bagaimana benda semakin cepat atau menjadi lambat ketika suatu gaya mengenainya. Perubahan kecepatan bergantung pada massa benda dan gaya yang mengenainya.

$$
\mathrm{a}=\frac{\sum \mathrm{F}}{\mathrm{m}}
$$

Rumus di atas memiliki keterbatasan dalam implementasinya, tinjauannya hanya berlaku untuk yang masa yang konstan (tidak berubah). Misalnya gerak roket yang sebagian masanya di isi oleh gas. Pada saat bergerak, massa roket berkuran setiap selang waktu.

Hukum III Newton menyatakan Hukum III newton menyatakan bahwa jika suatu gaya diberikan pada suatu benda (aksi), maka benda tersebut akan memberikan gaya yang sama besar dan berlawanan dengan gaya yang diberikan (reaksi), secara matematis ditulis:

$$
F_{\text {Aksi }}=-F_{\text {Reaksi }}
$$

Tanda (-) gaya reaksi berlawanan arah dengan gaya aksi. Ciri-ciri pasangan gaya aksi dan reaksi adalah kedua gaya sama besar, kedua gaya saling berlawanan arah, dan kedua gaya bekerja pada satu titik kerja gaya.

Secara umum pemikiran filsuf barat dan islam terhadap konsep dinamika gerak sangat bervariasi ada yang memandang secara kualitatif dan juga yang memandang gerak secara kualitatif. Namun, sering berjalannya waktu akhirnya pemikiran terhadap konsep gerak disempurnakan oleh Newton yang merupakan embrio munculnya teori fisika klasik Newton seperti digambarkan di bawah ini.

Berbagai temuan ilmiah yang menyentuh persoalan yang sama, tetapi dari perspektif yang berbeda, dengan titik-titik penekanan yang berbeda dan berakhir pada pandangan, serta dengan drajat kehebatan intelektual, kecanggihan yang berbeda pula (Nasution, 2016). Terminologi-terminologi yang digunakan dan gambaran terperinci yang mengkonseptualisasikan dinamika perilaku mengetahui manusia dapat berbeda dari satu metodologi dengan metodologi yang lain, tetapi seluruhnya bersifat kategoris dan menyatu dalam pandangan mereka ketika menekankan sifat hierarkis pengetahuan manusia dan Alam Semesta.

Pemikiran filsuf islam dan barat memiliki kesamaan dengan pemikiran Newton yaitu terkait yaitu sama-sama membahas tentang gerak yang terjadi di alam materi. Pada pemikiran keduanya mengatakan bahwa semua benda material bergerak, baik dipengaruhi faktor eksternal maupun internal. Faktor eksternal ini dalam bahasa Newton disebut dengan gaya yaitu penyebab dari perubahan gerak. Gaya dan gerak merupakan dua hal yang tidak dapat dipisahkan. Gaya diidentikkan sebagai dorongan atau tarikan atau gabungan dari keduanya yang menyebabkan benda bergerak cepat atau lambat, mengubah arah benda, dan mengubah bentuk benda (Resnick, 2001). Gaya dapat bekerja pada arah yang sama atau arah yang berlawanan. Beberapa gaya yang saling bertemu dengan arah berlawanan dapat saling meniadakan. Selain dari itu, dalam perjalanan sejarah pemikiran filsuf terdahulu maupun Newton, berpengaruh terhadap perkembangan sains modern. Misalnya, dalam filsafat Shadra sampai sekarang masih menjadi subjek kajian utama di pusat-pusat pengajaran tradisional di Iran, hingga akhirnya melahirkan suatu pemahaman baru yang disebut filsafat mazhab Qum. Begitu juga dengan Newton dalam kenyataan teknologi dan sains modern dari penemuan Newton sudah mencukupi dan memberdayakan manusia modern untuk memahami sistem dan mekanisme operasi jagat raya. Seperti pada lembaga-lembaga antariksa semacam NASA di USA

Menurut Nasution (2016) dalam merumuskan dimensi filosofis sains Islam, perlu kiranya mengkaji struktur keduanya, Pertama. Struktur keagamaan Islam, Islam sebagai agama terdiri atas tiga dimensi, Islam, Iman, dan Ihsan. Kedua. Sains secara struktural di bagi kepada empat komponen dasar, yaitu: pokok bahasan yang dirumuskan dengan baik (objek kajian), asumsiasumsi dasar yang berlaku sebagai fondasi epistemologies dari sains yang bersangkutan, metodologi kajian yang digunakan dalam sains tersebut, dan tujuan-tujuan yang berusaha dicapai oleh sains tersebut. Ketika menyelaraskan empat struktur sains dengan Islam, terlebih dahulu membahas asumsi dasarnya. Berdasarkan sifat dan status epistemologinya. Asumsi dasar bisa direduksi pada empat kategori, yaitu: Kategori berbagai pandangan atau keyakinan yang di persepsi, kategori berbagai pandangan atau keyakinan yang diterima secara umum, Kategori pengetahuan indrawi atau data empiris berdasarkan persepsi indra, Kategori prinsip- 
prinsip intelektual yang diterima secara intuitif. Dalam hal ini, asumsi-asumsi dasar kategori "keempatlah" yang memiliki kebenaran hakiki dan meyakinkan. Kebenaran-kebenaran dari berbagai asumsi dasar rasional yang berdasarkan intuisi dan logika yang dapat membangun kesempurnaan sebuah sains.

\section{Kesimpulan}

Berdasarkan hasil kajian literatur di atas, dapat ditarik beberapa kesimpulan sebagai berikut. Pemikiran filsuf barat dan islam pada pola berfikir mereka yang menjelaskan tentang fenomena gerak yang terjadi di tatanan alam semesta ini. Dapat dikatakan bahwa semua realitas pada dasarnya adalah dinamis. Karena selalu ada perubahan baik itu dipengaruhi faktor eksternal maupun bergerak dengan sendirinya. Pemikiran filsuf barat dan islam terkait konsep dinamika gerak sangat beragam tergantung cara pandang dan pikir mereka terhadap fenomena alam yang diamati.

Hubungan manusia, alam, dan Tuhan dapat digambarkan dalam tujuan sains. Dalam pandangan Islam menunjukkan kesatuan dan keterkaitan segala yang ada, sehingga dengan merenungkan kesatuan kosmos, manusia terdorong pada kesatuan prinsip llahi. Oleh sebab itu, sains dan Islam berkaitan dengan alam dapat dipandang dalam dua hal, Pertama, Sains dalam kacamata alam sebagai kesatuan tunggal dengan segala bagiannya saling terkait satu sama lain. Kedua. Sains dimaksudkan untuk mendorong baik saintis maupun filsuf untuk merenungkan alam sebagai ciptaan Tuhan. Keniscayaan untuk membahas realitas kosmik sebagai sebuah totalitas, maka kita akan melihat sifat Tuhan yang dinamis sebagai yang mendasari dan memelihara realitas dibalik semua kenyataan yang ada.

\section{Daftar Pustaka}

Al-Mandary, Mustamin,(ed.), Menuju Kesempurnaan Persepsi dalam Pemikiran Mulla Shadra, Makassar: Safinah, 2003

Akhyar, D. T. (1993). Sebuah Kompilasi Filsafat Islam, Semarang: DinaUtama.

Collette, A. T., \& Chiappetta, E. L. (1994). Science Intruction in the Middle and Secondary Schools $\left(3^{\text {rd }}\right.$ ed) New York: Merril

Fahham. A.M. (2004). Tuhan Dalam Filsafat 'Allamah Thabathaba'l. Bandung: Teraju PT Mizan Publika.

Farikhah, S. (2013). Perbandingan Teori Gerak Menurut Sadr al-Din al-Syirazi dan Isaac Newton. Undergraduate (S1) thesis, IAIN Walisongo. Open Akses. http://eprints. walisongo.ac.id/1536/.

Giancoli, D., \& Douglas. (2001). FISIKA Jilid I, Jakarta: Erlangga

Hambali, S. (2012). Pengantar Ilmu Falak Menyimak Proses Pembentukan Alam Semesta, Banyu Wangi: Bismillah Publisher.

Hanafi. A. (1996). Pengantar Filsafat Islam, Yogyakarta: Bulan Bintang.

Kartanegara, M. (2002). Menembus Batas Waktu, Fanorama Filsafat Islam, Bandung: Mizan.

Kartanegara, M. (2007). Mengislamkan Nalar Sebuah Respons Terhadap Modernitas. Jakarta: Erlangga hlm. 1-3.

Martini, S. (2016). Landasan Filsafat Konstruktivisme dalam Pembelajaran Sains. ISSN 25279939 Vol. I No.2 Februari 2017.

Nasution, M.A. (2016). Filsafat Sains Dalam Perspektif Pemikiran Islam. Tesis Program Pasca Sarjana Universitas Islam Negeri Sumatra Utara. Open Akses http://repository.uinsu.ac.id/1265/1/tesis\%20marlian.pdf

Putri, A., \& Alip, D. N. (2017).Pembelajaran Sains Berbasis Tradisi Sains Islam di Madrasah Tsanawiyah (Gerak Benda Menurut Ibnu Bajjah). Jurnal Phenomenon, Vol. 07 (No. 2), pp. 164-173.

Resnick, H., \& Walker. (2001). Fundamental of Physics,6th Edition. JohnWiley \& Son.

Shlomo, P. (1964). La dynamique d'Ibn Bajja" in Melanges Alexandre Koyre. Paris.

Supahar. (2014). The Estimation of Inquiry Performance Test Items of High School Physics Subject with Quest Program. Proceeding of International Conference on Research, 
Jurnal Filsafat Indonesia, Vol 1 No 12018

ISSN: E-ISSN 2620-7982, P-ISSN

Implementation and Education of Mathematics and Sciences 2014, Yogyakarta State University.

Tafsir. A. Filsafat Umum, Akal dan Hati Sejak Thales Sampai Capra, (Bandung: PT. Remaja Rosdakarya, 2009)., hlm. 257. 